\title{
The Effect of Tender Coconut Water on Free Radical Due to Mercury Exposure
}

\author{
Siti Thomas Zulaikhah, Joko Wahyu Wibowo \\ Department of Public Health, Faculty of Medicine, Universitas Islam Sultan Agung, Semarang, Indonesia
}

\begin{tabular}{l} 
Article Info \\
\hline Article history: \\
Received Feb 21, 2018 \\
Revised Jun 5, 2018 \\
Accepted Jun 30, 2018 \\
\hline
\end{tabular}

\section{Keyword:}

Free radicals

Glutation peroxidase

Mercury

Reactive Oxygen Species

(ROS)

Tender coconut water

\begin{abstract}
Mercury pollution can results from gold mining. Furthermore, a continuous mercury exposure can trigger the formation of Reactive Oxygen Species (ROS) and interfere with the body's antioxidant metabolism. A high level of free radicals in the body can be characterized by a low level of an antioxidant enzyme. Prevention to avoid the impacts of mercury poisoning is better than treatment. Tender coconut water can eliminate ROS and improve antioxidant status. This study aimed to was to confirm that tender coconut water is able to decrease the free radical which is characterized by increased antioxidant enzyme GPx status. This study was designed as randomized pre- and posttest control group design, 40 traditional gold mining workers devided into 2 groups: the control and treatment groups. After the pre test of GPx level, the workers were either given tender coconut water at the dose of $450 \mathrm{~m} \mathrm{~L}$ or water for 4 weeks every day. Four weeks after the pre-test, the level of GPx was assessed in the laboratory PAU-Gajahmada University. The post test results of the control group and treatments group were compared and analyzed using Man Whitney test. The mean levels of GPx post-test in the control group and treated group were $63.5 \pm 1.1 \mathrm{U} / \mathrm{mL}$ and $79.9 \pm 8.8 \mathrm{U} / \mathrm{mL}$ respectively. The analysis result obtained p-value 0.000 $<0.05$. Tender coconut water has an effect on free radicals due to to mercury exposure. Tender coconut water can be consumed daily to prevent degenerative diseases caused by mercury exposure.
\end{abstract}

Copyright (c) 2018 Institute of Advanced Engineering and Science. All rights reserved.

Corresponding Author:

Siti Thomas Zulaikhah,

Department of Public Health, Faculty of Medicine,

Universitas Islam Sultan Agung, Semarang, Indonesia.

Email: sitithomas@unissula.ac.id

\section{INTRODUCTION}

Mercury has been widely used in industrial processes such as thermometer industries, hydrometers, barometer, sphygmomanometer, fluoroscents lights, batteries, pesticides, plastics, sodas, chlor-alkalis and gold mining [1-3]. Globally, the largest source of mercury emissions comes from the small scale gold minings [3]. In Indonesia, there are around 57.5\% source of mercury emissions also comes from small scale gold minings with the total emissions of 195 tonnes/year [4]. Mercury is a free radical, this substance will bind thiol or sulfhydryl contained in antioxidant proteins so the antioxidant activity will decrease [5], [6]. This condition will cause depletion of glutathione and an increase in $\mathrm{H}_{2} \mathrm{O}_{2}$ due to inhibited activity of antioxidant enzymes [5]. Deficiency of one of the antioxidant components of the enzyme leads to a complete reduction in antioxidant status and will result in weak protection against ROS attacks [7], [8]. Elimination of ROS is very important to maintain the integrity of cell function and can be done by increasing the antioxidant activity [9]. Glutathione peroxidase (GPx) acts as a catalyst in breaking down $\mathrm{H}_{2} \mathrm{O}_{2}$ into oxidized glutathione (GSSH) using glutathione (GSH) as a substrate, GSSH will be reduced to GSH by glutathione reductase enzyme Mercury in the body is able to inhibit methioneine synthase (SM) in the methionine cycle and will interfere with GSH synthesis resulting in a decrease in GSH (GRed) [10], [11]. Mercury in the body is able to 
inhibit methioneine synthase (SM), in the methionine cycle and will interfere with GSH synthesis resulting in a decrease in GSH [12]. GSH is a substrate for the antioxidant glutathione peroxide (GPx) in breaking down hydrogen peroxide, if the glutathione system is disturbed it will cause a decrease in GSH and hydrogen peroxide will accumulate and eventually will increase the hydroxyl radicals more harmful to the human body. GSH is a substrate for the antioxidant glutathione peroxide (GPx) in breaking down hydrogen peroxide, if the glutathione system is interferred it will cause a decrease in GSH and hydrogen peroxide will accumulate and eventually will increase the hydroxyl radicals which can be harmful to the human body. The human body does not have antioxidant reserves in excess amount, so in case of exposure to free radicals, the body will need antioxidants that come from outside the body in order to eliminate the effects of free. Low level of antioxidant enzymes can be used as indicator that there is a high level of free radicals in the body [13], [14]. The body has protective mechanism to neutralize free radicals which is formed as gluthathione peroxidase (GPx) [13].

Tender coconut water has therapeutic effects, which contains various nutrients can be used to eliminate ROS and improve antioxidants status [15]. The results on animal testings indicated that administration of tender coconut water can improve antioxidant status and provide protection against damage caused by free radicals [15], [16]. This research aims to prove the administration of tender coconut water can decrease free radicals which indicated by the increase antioxidat status of GPx enzymes.

\section{RESEARCH METHOD}

The research design used is Randomized pre and post test control group design. In this design, there are four types of observation groups on research variables, the two groups are from initial results observation groups (O-1 and O-3), and two final observations results (O-2 and O-4) [17]. The design scheme as shown in Figure 1

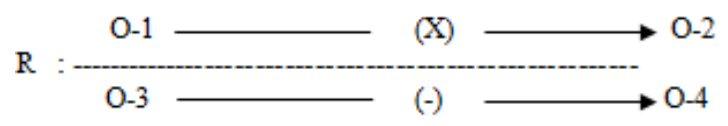

Figure 1. Randomized pre and post design test control group design

Description :

R : Randomization

(X) : administration of tender coconut water of $450 \mathrm{~mL} /$ day for 30 days (intervantion)

(-) : administration of water $450 \mathrm{~mL} /$ day for 30 days (control)

O-1 : Initial Observation Result (GPx Level) in treatment group (pretest)

O-2 : Final Observation Result (GPx Level) in treatment group (postest)

O-3 : Initial Observation result (GPx Level) in control group (pretest)

O-4 : Final observation result (GPx Level) in control group (postest)

Independent variable for this study was administration of tender coconut water $40 \mathrm{ml} /$ day for 30 days, the dependent variables were blood GPx levels, whereas the confounding variables include education, age, durations of contact, periods of work, BMI, personal protective equipment (PPE) and blood mercury levels. In order to obtain certainty that the changes occurring on the measured dependent variable are actually caused by the administration of $450 \mathrm{~mL} /$ day of tender coconut water for 30 days, it is necessary to control the arising confounding variables, through restriction and randomization.

To ensure that the control and the treatment groups before intervention had the same subject characteristics distribution, the comparative test analyzes were performed in both groups. Education, age, duration of contact with mercury, use of PPE, work period and nutritional status (BMI) were analyzed by Chi square test because the scale of the data were categorical data, while mercury was analyzed by independent t-test because the data scale was ratio and normally distributed.

The Subjects were traditional gold miner's workers in Wonogiri with the following criteria: male, age 20-60 years old, periods of working as miner for at least 5 years, normal nutritional status (BMI). Subjects who met selection criteria were randomized (R), so the treatment and control groups were formed, the bias factors can be controlled effectively because the confounding variables were divided evenly between two subject groups [17]. The number of sample of 40 randomly divided into 2 groups, which are control and treatment group. The treatment group was given tender coconut water $450 \mathrm{~mL} / \mathrm{day}$ for 30 days, and control

The Effect of Tender Coconut Water on Free Radical Due to Mercury Exposure (Siti Thomas Zulaikhah) 
group was given water for $450 \mathrm{~mL} /$ day for 30 days. The subjects as well as the researcher do not know into which groups the subjects are allocated (double blind). The first was conducting pre test by measuring the workers blood pressure to their GPx levels, four weeks after pre test, post test was conducted in both sample groups by measuring their GPx levels. The GPx levels were examined in the PAU laboratory-Gajah Mada University (UGM) by using RANSEL Glutathione. The first test performed was test for data normality since the data scale was rasio. The result of normality test using Shapiro-Wilk resulted that the distribution of data in both groups were not normally distributed $(\mathrm{p}<0.05)$, so the Mann Whitney test will be use to analyze the difference between the GPx levels after intervention (postest) in control and treatment groups [18].

\section{RESULTS AND ANALYSIS}

\subsection{Characteristics of the Subject}

The result of the analysis indicated that the distribution of characteristics of the subjects between treatment group and control group were no significant difference ( $p$ value $>0.05$ ). This situation indicated that the characteristics of the subjects between the control group and treatment group were even. All of the subjects have the blood mercury levels exceeding the WHO allowable treshold $(<10 \mu \mathrm{g} / \mathrm{L})$ as well as by Directorate of Medical Support Service Directorate General of Medical Care-Department of Health Republic of Indonesia in $2008(\leq 8 \mu \mathrm{g} / \mathrm{L})$. The complete result are illustrated in Table 1 .

Table 1. Distribution Characteristics of the Subjects between Treatment Groups and Control Groups

\begin{tabular}{|c|c|c|c|c|}
\hline No & Characteristics & Treatment & Control & p-value \\
\hline \multirow[t]{4}{*}{1.} & Education & & & \\
\hline & Elementary School & $1(5 \%)$ & $1(35 \%)$ & $0.943^{* \#}$ \\
\hline & Primary School & $13(65 \%)$ & $12(30 \%)$ & \\
\hline & Secondary School & $6(30 \%)$ & $7(35 \%)$ & \\
\hline \multirow[t]{3}{*}{2.} & Age (Years) & & & \\
\hline & Average $\pm \mathrm{SD}$ & $39.9 \pm 10.5$ & $41.8 \pm 8.4$ & $0.532 * \#$ \\
\hline & Min - Max (years) & $24-60$ & $29-60$ & \\
\hline \multirow[t]{3}{*}{3.} & Contact Duration (hours/day) & & & \\
\hline & $\geq 1$ hours/day & $17(85 \%)$ & $20(100 \%)$ & $0.072^{* \#}$ \\
\hline & $<1$ hour & $3(15 \%)$ & & \\
\hline \multirow[t]{3}{*}{4.} & PPE & & & \\
\hline & Never & $15(75 \%)$ & $20(100 \%)$ & $0.057^{* \#}$ \\
\hline & Sometimes & $5(25 \%)$ & & \\
\hline \multirow[t]{3}{*}{5.} & Period of Work (Year) & & & \\
\hline & Average \pm SD & $12.85 \pm 5.5$ & $14.8 \pm 5.5$ & $0.248^{* \#}$ \\
\hline & Min - Max (years) & $6-22$ & $6-25$ & \\
\hline \multirow[t]{2}{*}{6.} & Nutritional Status (BMI) & & & \\
\hline & Normal & $20(100 \%)$ & $20(100 \%)$ & ---- \\
\hline 7. & Average Mercury Levels \pm SD & $56.5 \pm 37.6$ & $74.6 \pm 52.4$ & $0.217^{\text {*\#\# }}$ \\
\hline
\end{tabular}

\subsection{Average Analysis for GPx levels of Control Group and Treatment Group}

The average level of Pre GPx in treatment group were $69.8 \pm 13.4 \mathrm{U} / \mathrm{mL}$ and control group were 69.7 $\pm 14.2 \mathrm{U} / \mathrm{mL}$, while the average of Post GPx levels in treatment group were $79.9 \pm 8.8 \mathrm{U} / \mathrm{mL}$ and control group were $63.5 \pm 1,0 \mathrm{U} / \mathrm{mL}$. The average levels of GPx in the control group and treatment group before the intervention were $\mathrm{p}=0.324$, this means that there was no difference of GPx levels before intervention in both groups. The result of analysis for average GPx levels after intervention in control group and treatment group was $\mathrm{p}=0.000$, it means that there were difference on GPx levels after intervention in both groups, in other words the administration of tender coconut water can increase GPx levels on traditional gold miners exposed to mercury. The complete results are illustrated in Table 2.

Table 2. Result of Average Analysis for GPx levels of Control Group and Treatment Group

\begin{tabular}{|c|c|c|c|}
\hline \multirow{2}{*}{ Variable } & \multicolumn{2}{|c|}{ Average $\pm S D$} & \multirow{2}{*}{ p-value } \\
\hline & Treatment Group (n:20) & Control Group (n:20) & \\
\hline Pre GPx Levels & $69.8 \pm 13.4$ & $69.7 \pm 14.2$ & $0.324>0.05^{*}$ \\
\hline Post GPx Levels & $79.9 \pm 8.8$ & $63.5 \pm 1.1$ & $0.000<0.05 *$ \\
\hline
\end{tabular}


The average result of GPx levels after intervention in the control group and the treatment group was $\mathrm{p}=0.000$, there was a difference of GPx levels after the intervention in both groups, meaning that the blood GPx level of traditional gold miners exposed to mercury were evidently increased after the administration of tender coconut water $450 \mathrm{~mL}$ every day for 30 days. This result is in accordance with Bhagya et al's research, Anurag and Rajamohan who stated that administration of tender coconut water can increase the levels of SOD and GPx antioxidants in experimental animals [15], [16]. This result is also linear with Zulaikhah's research, et al. which states that tender coconut water is able to increase levels of SOD and GPx in traditional gold miners exposed to mercury [19]. The difference between this study and previous research conducted by Zulaikhah et al. lies in the type of tender coconut water used during the treatment, tender coconut water originally derived from ordinary green coconut originating from Pacitan but this research uses the wulung tender coconut water originating from Purworejo and its surroundings, the age of the coconut fruit is about 5-7 months, and the antioxidant status measured is an enzyme antioxidant which is glutathione peroxidase (GPx) [19].

Tender coconut water contains antioxidants such as vitamin C, vitamin B1, vitamin B6, amino acids such as methionine, L-Arginine, selenium, cytokines and minerals that are very useful for protecting body cells from free radical attacks and preventing effects caused by mercury exposure [15], [20]-[23]. Tender coconut water is a source of methionine and vitamin B6 [23]. Methionine acts as a precursor for the formation of cysteine which is the main compound in the synthesis of glutathione (GSH). Methionine will be synthesized to S-adenosylmethionin (SAM) with the aid of a methionine adenosyltransfrease enzyme catalyst. Furthermore, S-adenosilmethionin (SAM) will be converted to S-adenosilhomocysteine (SAH), SAH will be converted to homocysteine with the help of enzyme adenosilhomosisteinase and by methionine synthase (MS) homocysteine can be converted back into methionine. In cysteine synthesis, homocysteine will be converted to cystationin with the help of cystathionine $\beta$ synthase (CBS) enzyme and vitamin B6 and then converted to cysteine with the help of the enzyme sistationin liase and vitamin B6, finally cysteine will be synthesized into glutathione (GSH) [12], [24], [25]. Tender coconut water contains selenium, which plays an important role in protein synthesis and GPx activity, the lack of selenium in the body can decrease GPx activity by up to $90 \%$ [26]. Mercury has a strong binding force against selenium [5], and both are antagonistic [27]. Giving young coconut water to workers exposed to mercury can be used as a source of selenium in order to increase GPx activity.

\section{CONCLUSION}

The average of GPx levels after intervention in the control group and treatment group was $\mathrm{p}$ value $=0.000$, there was difference on GPx levels after intervention in both groups which means the blood GPx levels of traditional gold miners exposed to mercury was proven to increase after the administration of tender coconut water of $450 \mathrm{~mL}$ every day for 30 days.

\section{ACKNOWLEDGEMENTS}

The researchers would like to thank FK Unissula for funding this research, PAU-UGM Yogyakarta, Wonogiri Regent, Sub-district Selogiri, Jendi Village Chief and traditional gold miners who were willing to be respondents.

\section{REFERENCES}

[1] D. Mergler et al., "Methylmercury Exposure and Health Effects in Humans: A Worldwide Concern," Ambio, vol. 36, no. 1, pp. 3-11, 2007.

[2] V. Varadharajan, "Restoration Of Antioxidant Avtivity By N-Acetylcysteine and Gallic Acid on Kidney Tissue of Mercury Chloride intoxicated Wistar Rats,”. Int. J. Biol. Pharm. Res., vol. 4, no. 4, pp. 302-307, 2013.

[3] UNEP, Global Mercury Assessment : Sources, Emissions, Releases and Environmental Transport. 2013.

[4] KESDAM, National Action Plan for the Elimination of Mercury in Gold Processing (in Bahasa) 2014-2018, 2013.

[5] SamZiff, "The Toxic time bomb can the mercury in your dental fillings poison you", 4th ed. USA: Aurora Pres, 2002.

[6] J. P. K. Rooney, "The role of thiols, dithiols, nutritional factors and interacting ligands in the toxicology of mercury," Toxicology, vol. 234, no. 3, pp. 145-156, 2007.

[7] L. Maslachah et al., "The Inhibition of Vitamin E ( $\alpha$-tocopherol) Antioxidant to Superoxide Radical Reactive Oxygen Species (O2') Production on the White Rat (Rattus norvegicus) Stressed by an Electric Shock" Media Kedokt. Hewan, vol. 24, no. 1, pp. 21-26, 2008.

[8] Halliwel B, "Oxygen Spesies Radikal in Living system. Source biochemistry and role in human decease," Am J, vol. 91, pp. 110-115, 1991.

[9] Q. H. AT Jan, A Ali, "Glutathione as an antioxidant in inorganic mercury induced nephrotoxicity," J. Postgrad.

The Effect of Tender Coconut Water on Free Radical Due to Mercury Exposure (Siti Thomas Zulaikhah) 
Med., vol. 57, no. 1, pp. 72-77, 2011.

[10] R. L. Murray RK, Granner DK, Roadwell V.W., "Harper's Illustrated Biochemistry" In: Wulandari N, Randy L, Dwijayanti L, Liena, Dany F, Biokimia Harper., 27th ed. Jakarta: EGC, 2009.

[11] A. Kunwar and K. . Priyadarsini, "Free radicals, oxidative stress and importance of antioxidants in human health," J. Med. Allied Sci., vol. 1, no. 2, pp. 53-60, 2011.

[12] Baker SM, "Who Ignores Individuality Fails the Patient," A Clin. J. New York, pp. 88-89, 2007.

[13] Hery Winarsi, "Natural Antioxidants \& Free Radicals", Yogyakarta: Kanisius, 2011.

[14] S. Astuti, "Soy isoflavones and their potential as free radical catchers (in Bahasa)" Teknol. Ind. dan Has. Pertan. Univ. Lampung, vol. 13, no. 2, pp. 126-136, 2008.

[15] T. R. D Bhagya, L Prima, "Therapeutik Effects of tender coconut water on oxidative stress in fructosa fed insulin resistant hypertensive rats," Asian Pasific J. Trop. Med., pp. 270-276, 2012.

[16] P Anurag and T Rajamohan, "Beneficial effect of tender coconut water against isoproterenol induced toxicity on heart mitochondrial activity in rats," Indian J. Biochem. Biophys., vol. 40, no. August, pp. 278-280, 2003.

[17] Sudigdo Sastroasmoro, "Fundamentals of Clinical Research Methodology", 5th ed. Jakarta: Sagung Seto, 2014.

[18] Dahlan MS, "The gateway understands statistics, methodology and epidemiology (in Bahasa)", Jakarta: Sagung Seto, 2014

[19] S. T. Zulaikhah and A. Suwondo, "Effects of Tender Coconut Water on Antioxidant Enzymatic Superoxida Dismutase ( SOD ), CATALASE ( CAT ), Glutathione Peroxidase (GPx) and Lipid Peroxidation In Mercury Exposure Workers," Int. J. Sci. Res., vol. 4, no. 12, pp. 517-524, 2015.

[20] B. Fife, Coconut Water for Health and Healing. USA: Piccadilly Books, 2008.

[21] R. Bhagya D, Prema L, "Tender coconut water maintains the level of electrolytes and renin in fructose-fed hypertensive rats," Int J Biol Med Res, vol. 1, pp. 44-48, 2010.

[22] P. J.-P. Alexia P, Dornier M, Diop N, "Coconut Water Uses, Composition and properties : a review," Fruits., vol. 67, pp. 87-107, 2011.

[23] J. W. H. Yong, L. Ge, Y. F. Ng, and S. N. Tan, "The Chemical Composition and Biological Properties of Coconut (Cocos nucifera L.) Water", Molecules, vol. 14, no. 12, pp. 5144-5164, 2009.

[24] A. Gulinar, "Antioxidant Effects of Sulfur-Containing Amino Acids," Yonsei Med. J., vol. 45, no. 5, pp. 7776-788, 2004.

[25] James SJ, "Metabolic biopetanda of increased oxidative stress and impaired methylation capacity in children with autism," Am j Clin Nutr, vol. 80, no. 6, pp. 1611-1617, 2004.

[26] Y. Fang, S. Yang, and G. Wu, "Free Radicals, Antioxidants, and Nutrition," Nutrition, vol. 18, no. 10, pp. 872-879, 2002.

[27] D.-Y. Yang, Y.-W. Chen, J. M. Gunn, and N. Belzile, "Selenium and mercury in organisms: Interactions and mechanisms," Environ. Rev., vol. 16, no. NA, pp. 71-92, 2008. 